\title{
STUDENTSKÁ ZPRÁVA O WORKSHOPU HLEDÁME JÁDRO PUDLA
}

\author{
ANEŽKA MATĚNOVÁ, TEREZA MATOUŠOVÁ
}

Jádro pudla hledal už Goethe. Jak ale praví přísloví, ve dvou se to lépe táhne, a jak pravíme my, ve třiceti ještě lépe. Zkrátka co nezvládl Goethe, jistě zvládneme my, řekli jsme si na pražské translatologii a nasedli na autobus do Lipska. Cestou jsme nabrali kolegy a kolegyně z Liberce.

Jako správní akademici jsme se nejdříve pustili do teorie a začali s výměnou vědeckých kynologických znalostí - vyučující se s námi v přednáškové sekci podělili o zkušenosti s př̀ekladem a souvisejícími tématy, jako jsou různé podoby výuky překladatelství či jazykový výzkum. Odpoledne se neslo v duchu hledání slovanských stop, jež byly rozesety po celém městě, a večer jsme se dostavili k přednesu Pavla Novotného. Pohltilo nás nadšení a očividná radost básníkova z přednesu jeho vlastních básní i jejich německých překladů. Cítili jsme jaksi, že se jádro pudla vznáší mezi námi. Ovšem jako translatologové jsme se nemohli spokojit s nějakým pocitem, a jelikož jsme stále nebyli schopni ono jádro postihnout, pustili jsme se do terénní práce.

Jádro pudla jsme se pokoušeli hledat další dva dny hlavně na workshopech v avantgardní poezii a v dětské próze pod taktovkou (či spíše křídou) Pavla Novotného a Radka Malého. Překládali jsme ve smíšených česko-německých skupinách. Měli jsme možnost výchozí text analyzovat ve skupině a diskutovat svoje řešení. Na konci každého workshopu proběhlo čtení, v př́ípadě básní spíše recitace vytvořených překladů. Recitace překladů na konci prvního dne workshopu asi mohla vypadat militantně: stáli jsme v kruhu a stříleli po sobě různými překlady téže avantgardní básně o vojáku Tomovi. A Benovi. I o Frantovi... Jelikož přednášeli všichni naráz, vytvořili jsme pořádnou bitevní vřavu. Pak jsme se ovšem upamatovali na zásady kultivované vědecké spolupráce a vypravili se docela civilizovaně a mírumilovně do divadla, které bylo podobně neobvyklé a intenzivní jako námi překládané texty - tentokrát jsme nemuseli přemýšlet nad formulací v češtině, ale mohli se nechat volně unášet jeho průběhem...

Většina $\mathrm{z}$ nás pravděpodobně hledala jádro pudla poprvé. Snad máme určité zkušenosti s hledáním jádra jiných psích plemen - na pražské translatologii se obvykle zabýváme překladem publicistických a odborných textů. Navíc ani v rámci literárního překladu není avantgardní poezie zrovna nejběžnější výukový materiál. Nezvyklé typy textů čili pudlí element byly zkrátka něco zcela mimořádného, co nám mělo pomoci v naší překladatelské evoluci. Těžko ale říct, zda se některá naše řešení jádru pudla blížila. Spíše jsme zjistili, že jej náš soubor jedinečných řešení teprve vytvářel, naše práce načrtla jádra literárních textů jako množinu interpretací, překladatelských problémů a jejich řešení. 
Goethe tedy může být klidný, celé jádro pudla jsme skutečně neobjevili. Nějaké to jadérko se však přece jen během pobytu v Lipsku vylouplo. Ještě aby ne. Vždyt se na jednom malém (až stísněném) prostoru sešli dva vynikající překladatelé s námi, studenty, kteří se za pravidelně doplňované hladiny kofeinu a cukru v krvi do pátrací akce pustili zapáleně, či přinejmenším ochotně. Sborník, jejž laskavý čtenář právě drží v ruce, představuje výsledek našeho společného snažení. Kdoví, třeba jadérko vzklíćí a přinese zajímavý čtenářský zážitek. Možná tomu napomůže i skutečnost, že na něj skoro celé ty tři dny pršelo.

Bc. Anežka Matěnová studentka Ústavu translatologie Filozofické fakulty Univerzity Karlovy a.matenova@seznam.cz

Bc. Tereza Matoušová studentka Ustavu translatologie Filozofické fakulty Univerzity Karlovy terezka@matousova.cz 